\title{
Application of the New Self-dynamisable Internal Fixator in the Treatment of Femoral Shaft Fractures
}

\author{
Milan Mitković1, Saša Milenković1,2, Ivan Micić1,2, Predrag Stojiljković1,2, Igor Kostić1,2, \\ Slobodan Milenkovićs, Dražen Jelača ${ }^{4}$, Milorad Mitković ${ }^{2}$ \\ ${ }^{1}$ Clinic of Orthopedics and Traumatology, Clinical Center Niš, Niš, Serbia \\ ${ }^{2}$ University of Niš, Faculty of Medicine, Niš ,Serbia \\ ${ }^{3}$ Orthopedics and Traumatology Ward, General Hospital Vranje, Vranje, Serbia \\ ${ }^{4}$ Orthopedics and Traumatology Ward, General Hospital Pančevo, Pančevo, Serbia
}

\section{SUMMARY}

The aim of this study was to present the results of one original method application in internal fixation of long bones.

The series of 27 patients with unilateral fractures of femoral shaft was analyzed. According to AO classification, 21 fractures were classified as $32 \mathrm{~A}$, five as $32 \mathrm{~B}$, and one as $32 \mathrm{C}$ type. Original diaphyseal selfdynamisable internal fixator (model 1) was used as a fixation implant, consisting of three components: specially designed extramedullary bar, clamps and screws. The main feature of this implant is a possibility to become dynamic in the axial direction spontaneously if there is no sufficient fracture healing. Because of that, this implant is known as an "intelligent implant “. Surgical method included a standard surgical approach and minimally invasive surgical approach.

Minimally invasive technique of application required less blood transfusion and shorter surgery time when compared to the standard surgical approach. The duration of used intraoperative fluoroscopy control was 7(3-18) seconds. The average healing time was 4.3 (3.5-9.5) months. There were neither intra operative nor postoperative complications.

In comparison to intramedullary nails, self-dynamisable internal fixator provides a similar treatment results, while in comparison to plates it provides fewer mechanical complications. Self-dynamisable internal fixator method preserves periosteal and intramedullary blood circulation, and it is the first fixation implant with a possibility of spontaneous axial dynamising activation when needed.

This implant has been proven as suitable for routine use in the treatment of femoral shaft fractures.

Key words: femur, fracture, internal fixation, dynamization, vascularization

Corresponding author:

Milan Mitković

E-mail: milanmitkovic@hotmail.com 


\section{INTRODUCTION}

Fractures of femoral shaft are considered as a major challenge for the orthopedic surgeons. These fractures occur as a consequence of strong force effect, often in traffic accidents. Diaphyseal femoral fractures are hence common injuries in polytraumatized patients. Due to the muscles and blood vessels tear, there is significant bleeding with average blood loose of 700-1000 ml. This blood loss has to be followed by blood transfusion immediately as blood loss can be fatal, especially in cases with bilateral femoral fractures. Today's concept of "damage control“ includes primary external fixation regardless of whether they are open or closed. Definitive fixation is performed in the second act by internal fixation mostly (1). Internal fixation is usually achieved by intramedullary nailing or by plating (2-5). During the application of an intramedullary nail, it is necessary to ream the intramedullary canal, but this reaming destroys intramedullary blood vascularization. This fixation is good but application is technically demanding, and implant removal at the end of the treatment can be difficult. Plate fixation is a less commonly used method today in the treatment of femoral shaft fractures because there is no possibility of axial dynamization and because of periosteal vascularization damage. This paper presents the results of an original method application using a device for internal fixation: self-dynamisable internal fixator (SIF) having the features to preserve both intramedullary and periosteal vascularization and to activate axial dynamization spontaneously, when needed.

\section{MATERIAL AND METHODS}

\section{Patients}

This retrospective study included 27 patients, 13 males and 14 females, with a unilateral fracture of the femoral shaft. The mean age was 44 years. According to $\mathrm{AO}$ classification (2), 21 fractures were classified in group $32 \mathrm{~A}$, five in group 32B, and one in group $32 \mathrm{C}$.

These patients underwent surgical treatment in three different centers: Clinic for Orthopedics and Traumatology in Clinical Centre Niš, Orthopaedics and Traumatology Ward in General Hospital Vranje and Orthopedics and Traumatology Ward in General Hospital Pančevo, during the period from January $1^{\text {st }}$ to December 31st 2014.

All the patients were treated using the same surgical technique and implant - model 1 of diaphyseal self-dynamisable internal fixator. Three surgeons used a minimally invasive application with 2-3 incisions, about 3-4 cm long each. Other surgeons used longer incisions. Wound drainage was applied in $77.7 \%$ of fractures. Patients were routinely transferred to the intensive care unit postoperatively. The analyzed parameters in this paper were: surgery time, intra operative fluoroscopy control time, intraoperative complications, intensive care time, blood transfusion, postoperative complications (infection, delay union and nonunion, thromboembolism and mechanical complications) and healing time. Patients were allowed to start with full weight bearing within 1 to 8 weeks after surgery, depending on the fracture type. Statistical analysis was performed using a Student's t-test.

\section{Implant characteristics}

Diaphyseal self-dynamisable internal fixator (SIF) - model 1 (6) (Traffix DOO Niš, Serbia) consists of the three components: specially designed bar, clamps and screws (Figure 1 and Figure 2).

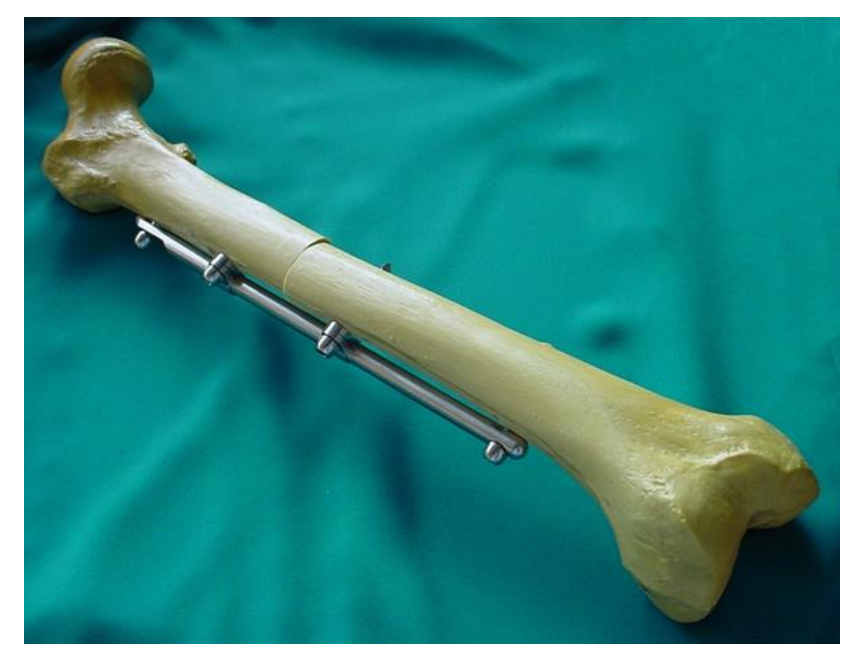

Figure 1: Self-dynamisable diaphyseal internal fixator (SIF) for the femur. There is no direct contact between the bar and the bone in the fracture area

At one end of the bar, there is a round hole for a static anti-rotation screw, and at the opposite side of the bar there is a dynamic anti-rotation unit with an oblong hole for dynamic anti-rotation screw. Other screws are applied through the clamps and bones. It is not recommended to use more than two clamps for one main bone fragment. Thus, in a femoral shaft fracture two clamps are used for the main proximal fragment and two clamps also for the main distal fragment. One (static) anti-rotation screw is applied through the round hole in the bar, and another 
(dynamic) anti-rotation screw is applied through the oblong hole in a dynamic unit of the bar. It is very important for the screw in the dynamic unit to be applied as near to the tip of the bar (peripheral border of the oblong hole) as possible.

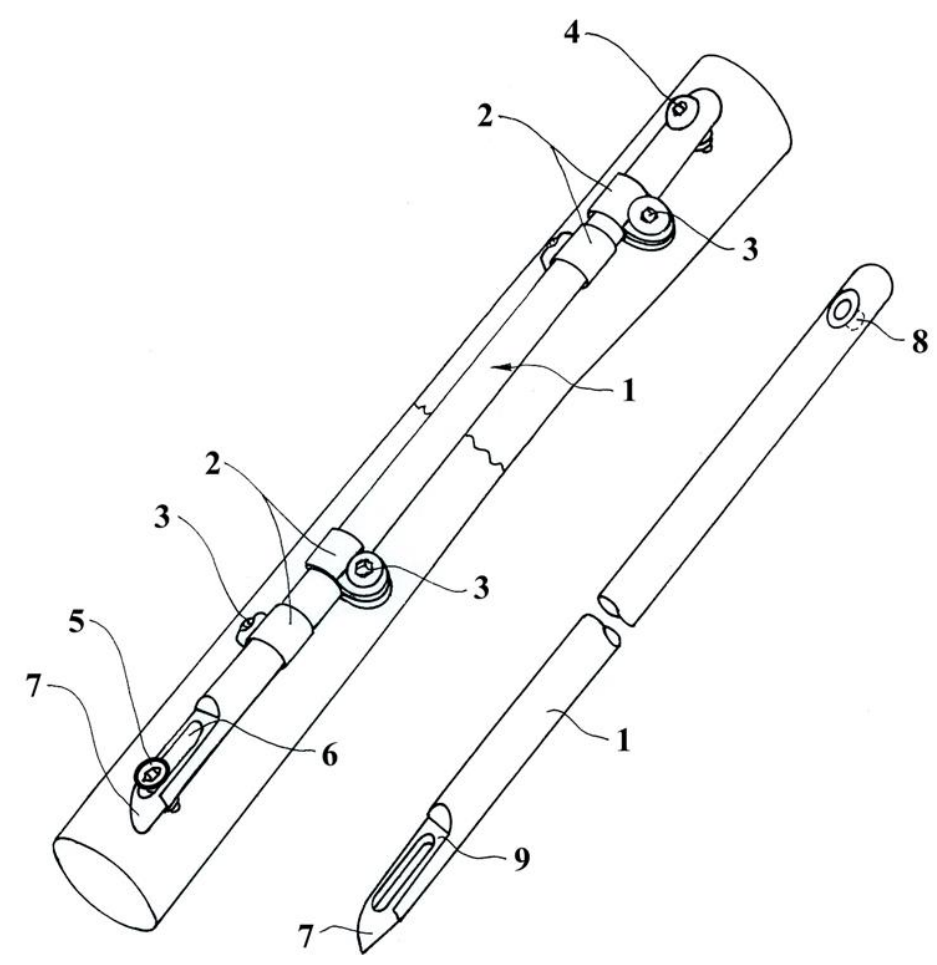

Figure 2: A drawing of self-dynamisable diaphyseal internal fixator (SIF). 1-bar; 2-clamps; 3-screws for clamps; 4-static anti-rotation screw; 5-dynamic anti-rotation screw; 6-oblong hole on the bar; 7-tip of the bar; 8-round hole on the bar; 9-dynamic unit of the bar. It is very important that dynamic anti-rotation screw be intraoperatively placed at the peripheral border of the oblong hole (near to the tip of the bar).

In that case, the maximum possible dynamization is $18 \mathrm{~mm}$. If that screw is applied at the opposite side of the oblong hole (far from the tip of the bar), then capacity for dynamization is zero - actually, there is no possibility for dynamization. In that case, the implant is not self-dynamisable, and it functions as a plate with high possibility of postoperative mechanical complications' occurrence. After 4-6 weeks from surgery, the new bone callus is giving a contribution in the fracture stabilization. This contribution is absent if there is no sufficient fracture healing, and screws for clamps (Figure 2) hence become slightly loosed due to the action of forces induced by body weight during walking and by muscles forces and leg movements. That mild clamps loosening provide spontaneous clamps unlocking and automatic sliding of the bone fragment along the bar. That sliding, known as axial dynamization, leads to bone fragments contact in the fracture area, stimulating thus the fracture healing.
If the fracture healing is normal then dynamization is not activated. Therefore, this implant is known as an „intelligent implant". This unique implant is also known under the inventor's name, as „Mitkovic Internal Fixator". It is an internationally recognized patent. Self-dynamisable internal fixators for different parts of the femur, tibia and humerus have already been applied to more then six thousand patients.

\section{RESULTS}

Surgical interventions were performed 2-7 (average 4.2) days after injury. All patients were admitted to the hospital on the day of injury. The mean values of the followed parameters are presented in Table 1.

Minimally invasive technique decreases blood transfusion requirements. This technique was applied in 6 patients. Figure 3 and Figure 4 show the X-rays of a 20 -year-old patient before and after the surgery. 
Table 1: Average values of analyzed clinical parameters in the whole series

\begin{tabular}{c|c}
\hline \hline Parameter & Value \\
\hline Surgery time (min) & $79.5(45-130)$ \\
\hline Time of intraoperative fluoroscopy (seconds) & $7(3-18)$ \\
\hline Intraoperative complications & - \\
\hline Time of intensive care (days) & $3.1(1-7)$ \\
\hline Postoperative blood transfusion after minimally invasive technique (ml) & $233.3(0-700)$ \\
\hline Postoperative blood transfusion after regular surgical exposure $(\mathrm{ml})$ & $750(350-1050)$ \\
\hline Postoperative mechanical complications & - \\
\hline Delayed union and nonunion & - \\
\hline Infection & - \\
\hline Thromboembolism & $4.3(3.5-9.5)$ \\
\hline Healing time (months) & - \\
\hline \hline
\end{tabular}

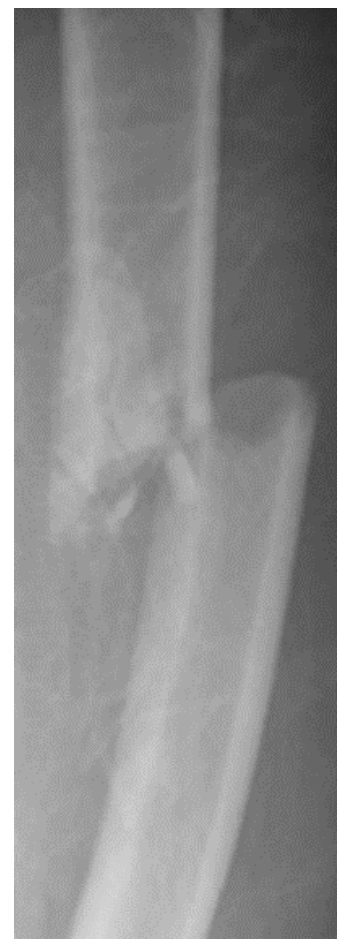

Figure 3: An X-ray of the femur shaft fracture in a 20-year-old man

Postoperative clinical recovery (full knee and hip joint function ten weeks after the surgery) is presented in Figure 5 and Figure 6. Relatively small postoperative scars are visible in these figures after minimally

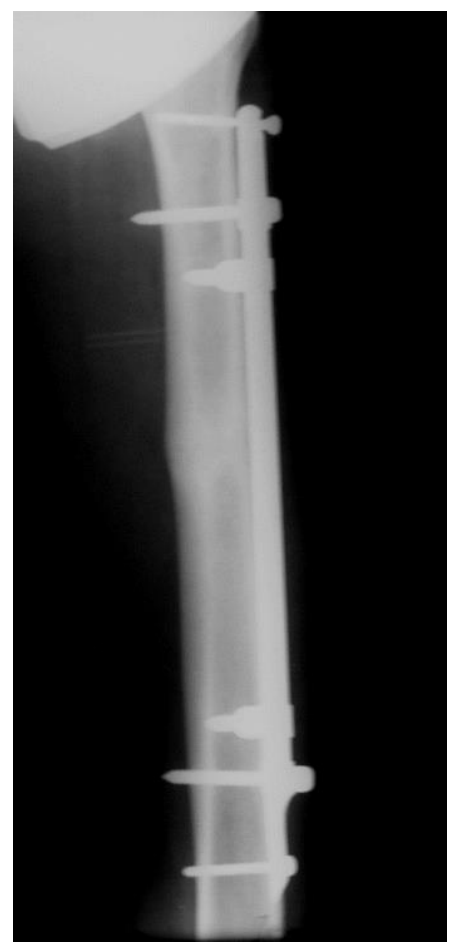

Figure 4: An X-ray of the patient from Figure 3, sixteen months after internal fixation by SIF.

invasive operative approach had been used in this case. Table 1 shows an average intraoperative fluoroscopy time, which was 7 seconds only. 


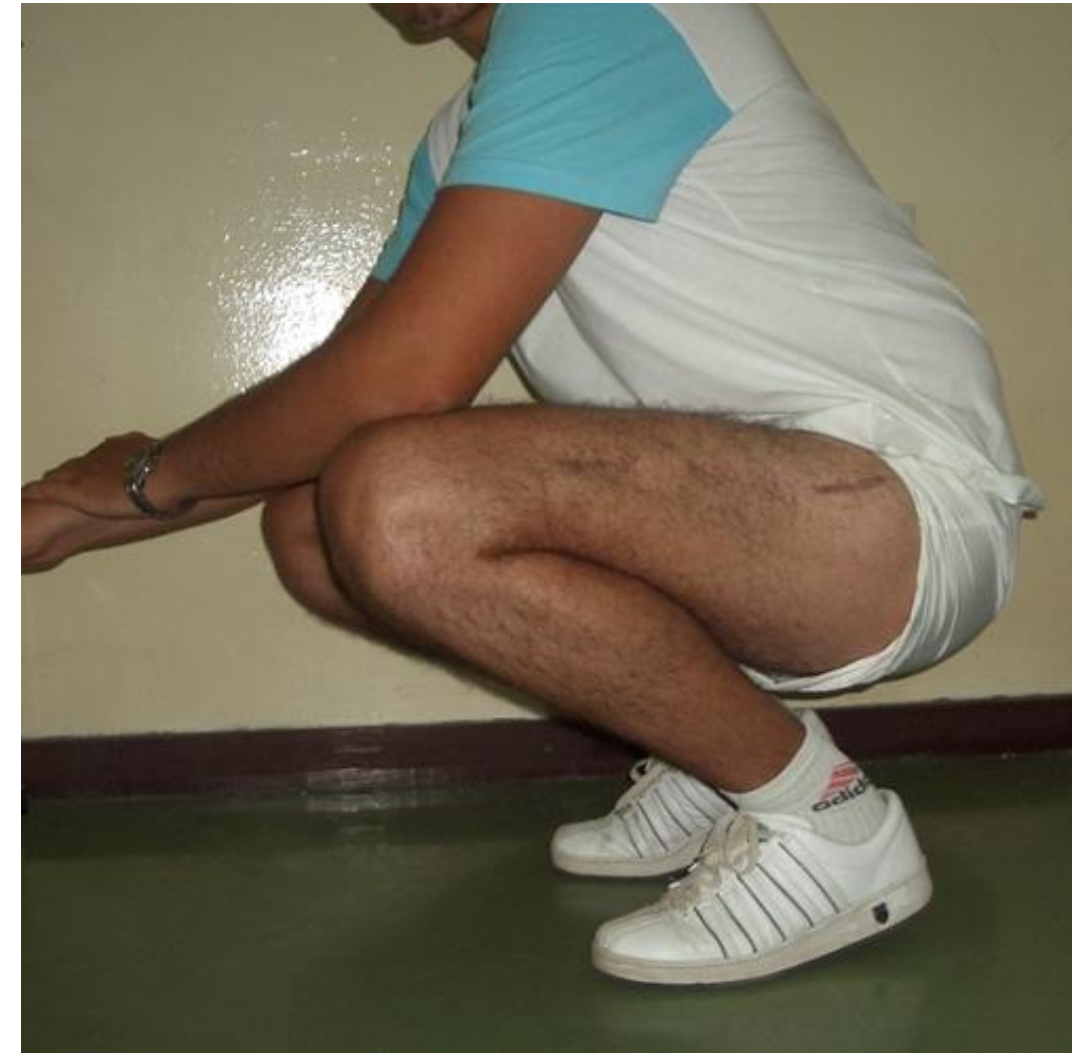

Figure 5: The same patient from Figure 3, ten weeks after the surgery; there is a full knee and hip flexion

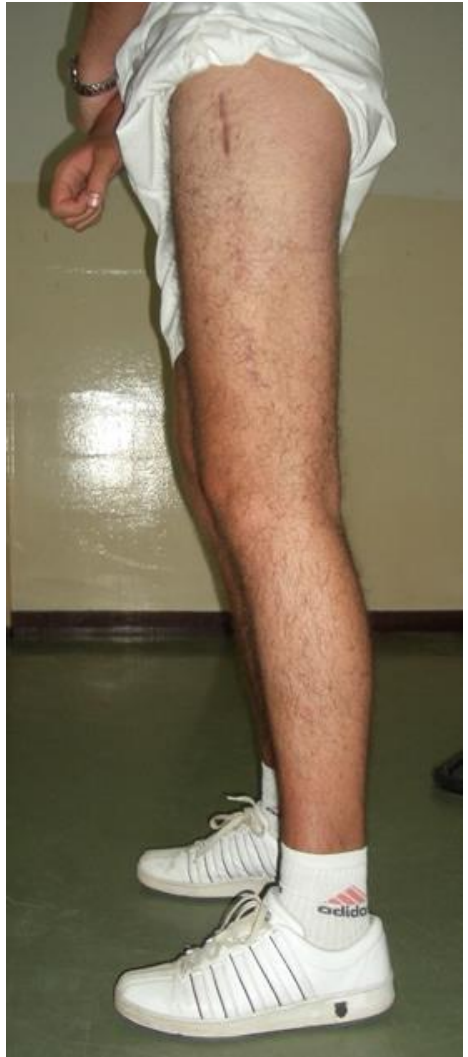

Figure 6: The same patient from Figure 3, ten weeks after the surgery; standing and full weight bearing are possible
There were neither intraoperative nor postoperative complications. It should be mentioned that a minimally invasive method (though small incisions) has advantages in regard to required blood transfusion. There were no mechanical complications, delayed union or non-union, infection or thromboembolism during the period of two years. Most patients treated by SIF did not have complains regarding pain, except one patient with temporarily mild complaint. Spontaneous axial dynamization was detected on X-ray in 7 cases (25.9\%).

\section{DISCUSSION}

Femoral shaft fractures are presented as a challenge in everyday traumatology practice. These injuries are induced by high energy forces and followed by massive bleeding. The treatment of femoral shaft fractures is often a life support. Several different surgical methods for fixation of these fractures have been in used until now. Among them, the most impressive, during the history of femur fixation, was the use of Kuntscher intramedullary nail. This system has some advantages, especially when it comes to good alignment of fragments, due to the nail insertion into the bone canal, since the long bone of femur is actually a tube. However, this system was not stable enough with regard to rotation, being the reason for the occurrence of complications, such as delayed union or non-union. This nail is axially dynamic, providing permanent contact between bone fragments. However, it was a reason for a considerable protrusion of the nail into the trochanteric and knee areas, causing pain and skin perforation, followed by infection. The use of plates can lead to non-union and/or implant failure (7). Today, the gold standard for the surgical treatment of femoral shaft fractures is the use of locking intramedullary nails (8-10). Contemporary intramedullary nails yield high union rate and low complications rate in the treatment of femoral shaft fractures, especially when thorough preoperative planning and correct postoperative follow-up are performed. Intramedullary nailing has two main advantages: it is a minimally invasive method and immediate weight-bearing is commonly allowed.

The desirable effect of axial dynamization is 
today well recognized. The interlocking nail provides such a possibility $(9,10)$. To activate axial dynamization of the interlocking nail, it is necessary to perform an additional operation. New models of plates minimize disadvantages of classical plating regarding cortical perfusion preservation, but complications relating to delayed union (up to 6.1\%) and implant failures (up to $7.4 \%)$ still exist $(11,12)$.

Dynamization is important, but not for all patients. Some studies showed that dynamization requirement to achieve shaft fractures union in patients who underwent statically locked intramedullary fixation was $11.6 \%$ in one article (13) and $21 \%$ in another one (14). Removal of the locking screw provides dynamization and accelerates the transformation and ossification of early formed callus. Some of the authors, as $\mathrm{Wu}$, believe that dynamization can accelerate fracture union, but cannot prevent non-union. In our series, dynamization was spontaneously activated in 7 patients (25.9\%). According to the literature data and to our early experience with the SIF, there can be concluded that dynamization is desirable in about $20 \%$ of patients with femoral shaft fractures. We do not know in advance which fractures (patients) will need dynamization. Using the bar and clamps, there is no contact in the fracture area between bone and the bar. From the biomechanical point of view, the SIF provides a balanced three-dimensional stability in the fracture area. This has been confirmed by biomechanical investigation on 60 animals (6). The SIF provides three-dimensional stability as screws can be introduced in up to about $45^{\circ}$ of convergent orientation. This implant is also sufficiently elastic to stimulate the production of periostal callus. The effect of spontaneous axial dynamization has been proven radiologically. Biomechanical investigations of forces related to the SIF have been performed under different conditions (15). Delayed union and nonunion are decreased. As dynamization can be activated spontaneously, this internal fixator is also known as the „intelligent implant".

\section{CONCLUSION}

According to the results obtained after the use of SIF in the treatment of femoral shaft fractures, it can be concluded that this implant provides good biological and biomechanical conditions for femoral shaft fracture healing. It is especially suitable for the treatment of complex fractures, such as comminuted fractures and segmental fractures. Operative technique is relatively simple and this implant can be routinely used in minimally invasive osteosynthesis. Further studies, however, are necessary to define the optimal momentum of the force during the screw tightening. 


\section{References}

1. Dong C, Wang Y, Wang Z, et al. Damage Control Orthopedics Manage ment as Vital Procedure in Elderly Patients with Femoral Neck Fractures Complicated with Chronic Renal Failure: A Retrospective Cohort Study. PLoS One 2016 May 5;11(5). https://doi.org/10.1371/journal.pone.0154906

2. Müller ME, Allgöwer M, Schneider R, Willenegger H. Manual of internal fixation. 3. New York: Sprin ger-Verlag; 1991.

https://doi.org/10.1007/978-3-662-02695-3

3. Weise K. 30 years of osteosynthesis: developments in surgical fracture treatment over the last three decades. Orthopade 2010;39:122-131. doi: 10.1007/ s00132-009-1517-4.

https://doi.org/10.1007/s00132-009-1517-4

4. Ricci WM, Gallagher B, Haidukewych GJ. Intrame dullary nailing of femoral shaft fractures: current concepts. J Am Acad Orthop Surg 2009;17:296-305. https://doi.org/10.5435/00124635-200905000-00004

5. Bishop JA, Rodriguez EK. Closed intramedullary nailing of the femur in the lateral decubitus position. J Trauma 2010;68:231-235. https://doi.org/10.1097/TA.0b013e3181c488d8

6. Mitkovic MB, Milenkovic S., Micic Iet al. Results of the femur fractures treated with the new selfdynamisable internal fixator (SIF). European J Trauma Emerg Surg, doi 10.1007/s00068-011-01577.

\section{https://doi.org/10.1007/s00068-011-0157-7}

7. Stoffel K, Dieter U, Stachowiak G, et al. Biomechanical testing of the LCP-how can stability in locked internal fixators be controlled? Injury 2003;34(Suppl 2):B11-B19.

https://doi.org/10.1016/j.injury.2003.09.021
8. Montanini R, Filardi V. In vitro biomechanical evaluation of antegrade femoral nailing at early and late postoperative stages. Med Eng Phys 2010; 32:889897.

https://doi.org/10.1016/j.medengphy.2010.06.005

9. Basumallick MN, Bandopadhyay A. Effect of dynamization in open interlocking nailing of femo ral fractures. A prospective randomized compara tive study of 50 cases with a 2-year follow-up. Acta Orthop Belg 2002;68:42-48.

10. Mukhopadhyay AS, Mukherjee J, Sengupta A. The role of dynamisation vis-à-vis non-dynamisation after closed interlocking nailing in cases of closed tibial shaft fractures in adults. J Indian Med Assoc 2010;108:361-362.

11. Schütz $M$, Müller $M$, Kääb $M$, Haas N. Less invasive stabilization system (LISS) in the treat ment of distal femoral fractures. Acta Chir Orthop Traumatol Cech 2003;70:74-82.

12. Schütz M, Südkamp NP. Revolution in plate osteosynthesis: new internal fixator systems. J Orthop Sci 2003;8:252-258. doi: 10.1007/ s007760300044.

https://doi.org/10.1007/s007760300044

13. Lepore L, Lepore S, Maffulli N. Intramedullary nailing of the femur with an inflatable self-locking nail: comparison with locked nailing. J Orthop Sci 2003;8:796-801.

https://doi.org/10.1007/s00776-003-0709-8

14. Erturer E, Tekkes, in M, Dirik $Y$, et al. Radiographic and functional results of osteosyn thesis with locked intramedulary nailing of subtro chanteric fractures of the femur. Acta Orthop Trau matol Turc 2004;38:265-269.

15. Mitković MM, Manić MT, Petković DLj, et al. Dynamic forces of Mitko vic self-dinamysible trochanteric Internal fixators (SIF). Acta Chir Iugosl 2013;60(2):87-91. 


\title{
Primena novog samodinamizirajućeg unutrašnjeg fiksatora u lečenju preloma dijafize femura
}

\author{
Milan Mitković ${ }^{1}$, Saša Milenković1,2, Ivan Micić1,2, Predrag Stojiljković1,2, Igor Kostić, ${ }^{1,2}$, \\ Slobodan Milenković3, Dražen Jelača ${ }^{4}$, Milorad Mitković \\ ${ }^{1}$ Klinika za ortopediju i traumatologiju, Klinički centar Niš, Niš, Srbija \\ ${ }^{2}$ Univerzitet u Nišu, Medicinski fakultet, Niš, Srbija \\ ${ }^{3}$ Opšta bolnica Vranje, Ortopedsko-traumatološko odeljenje, Vranje, Srbija \\ ${ }^{4}$ Opšta bolnica Pančevo, Ortopedsko-traumatološko odeljenje, Pančevo, Srbija
}

\section{SAŽETAK}

Cilj ovog rada bio je da prikaže rezultate primene nove originalne metode $i$ uređaja za unutrašnju fiksaciju preloma dugih kostiju.

Kao klinički materijal analizirali smo seriju od 27 bolesnika sa prelomom dijafize femura. Prema AO klasifikaciji zabeležen je: 21 prelom tipa 32A, 6 preloma tipa 32B i jedan prelom tipa 32C. od implantata je korišćen samodinamizirajući unutrašnji fiksator (model 1), koji se sastoji od tri komponente: specijalne šipke, spojnica i zavrtnja. U toku hirurške intervencije korišćene su dve hirurške tehnike: klasičan i minimalno invazivan hirurški pristup.

Rezultati su pokazali da je primenom minimalno invazivne ugradnje implantata potrebna manja količina krvi koju treba nadoknaditi u toku i posle operacije. Dužina rendgenske fluoroskopije bila je 7 (3-18) sekundi. Vreme zarastanja preloma bilo je $4,3(3,5-9,5)$ meseca. Nije bilo intraoperativnih niti postoperativnih komplikacija. Spontana aksijalna dinamizacija bila je registrovana kod 7 pacijenata $(25,9 \%)$.

U poređenju sa intramedularnim klinom, prema podacima iz literature, samodinamizirajući unutrašnji fiksator obezbeđuje slične rezultate lečenja, dok u poređenju sa primenom ploča pokazuje superiornost, jer istovremeno obezbeđuje i mogućnost sponatane aksijalne dinamizacije kada je zarastanje usporeno i očuvanje kako intramedularne tako i periostalne vaskularizacije.

Samodinamizirajući unutrašnji fiksator pogodan je za rutinsku primenu u lečenju preloma dijafize femura.

Ključne reči: femur, prelom, untrašnja fiksacija, dinamizacija, vaskularizacija 